\title{
Outcomes-Based Education: Teachers' Attitude and Implementation
}

\author{
JOY BONGABONG-BAGUIO \\ jbbaguio@universityofbohol.edu.ph \\ https://orcid.org/0000-0002-1957-9564
}

\begin{abstract}
Assessing teachers' attitude in the implementation of Outcomes-Based Education (OBE) is essential for the success of this new paradigm shift in the educational system. This study used a descriptive research design where the researcher gathered quantitative data utilizing a survey questionnaire to assess the attitude fostered by the teachers of the University of Bohol towards OBE. It further assessed the level of its implementation in the four major areas: formulation and alignment of learning outcomes, curriculum content and structure, teaching-learning process, and assessment. Findings of the study revealed that the respondents' age, length of teaching experience, and highest educational attainment have no direct relationship towards OBE implementation. However, the respondents' age is directly related to the level of its implementation. Results also revealed that teachers who have a highly favorable attitude towards OBE are more motivated and willing to carry out the overall processes that necessitate OBE implementation.

For a change in education to be effective and long-lasting, teachers need to view the entire OBE process as desirable and necessary. With a strong determination and purpose combined with a collaborative effort between the school administrators, teachers, students, and other stakeholders, indeed successful implementation of this newly adopted curriculum in the higher education institutions will reach far beyond one could imagine.
\end{abstract}


Keywords: Outcomes-Based Education, curriculum, quantitative method, Bohol, Philippines

\section{INTRODUCTION}

Outcomes-Based Education (OBE) is the main thrust of the Higher Education Institutions in the Philippines today. The Commission on Higher Education (CHED) Memorandum Order (CMO) No. 46, s. 2012 articulated this form of competency-based learning standards and outcomes-based quality assurance monitoring and evaluation (De Guzman, Edaño, \& Umayan, 2017).

One of the significant parts of OBE processes involves determining the measurable and suitable outcomes for the students. This approach is said to be on track to changing the educational system from inputs based to outputs based. Thus, the OBE is said to be the key to student success in learning and assuring a high level of employability in the future.

According to De Guzman et al. (2017), the introduction of OBE in the higher education system resulted in many issues and concerns such as a significant shift in the teaching practices and different assumptions and viewpoints of the OBEss value to the system and the students. Moreover, educators> educational beliefs about OBE can act as a challenge or enabler for its full implementation. Despite all these problems, challenges, and adjustments, the educational system has the responsibility to ensure that its educational programs surpass in all aspects and respects. Hence, full understanding and knowledge of the real essence of OBE and its application in the teaching-learning process are what the educators and administrators need today.

This paradigm shift adaptation in the education system challenged educators to engage and act as learner facilitators rather than conveyors of knowledge and information (Ortega and Ortega-Dela Cruz, 2016). Positive attitude and full internalization of the essence of OBE is essential for its implementation.

The researcher decided to look into the attitude of the teachers of the University of Bohol towards Outcomes-Based Education, and assess the level of its implementation. The findings of this study would become the basis of benchmarking. Further, it will also motivate the teachers to become more effective and efficient in the total organization of their classroom delivery and instruction using the OBE principle. 
Different theories support the implementation of OBE. First is Bloom's Mastery Learning Theory (Bloom, 1968) stated that the fundamental task in education is to find strategies which will consider individual differences but in such a way as to promote the fullest development of the individual. Next is the Tyler Model, which begins by defining the objectives of the learning experience (Keating, 2014). The model focuses primarily on the product rather than the process for achieving the goals and objectives of the curriculum. Another theory is the Theory of Behavioral Objectives by Mager (Dalton, 2014). This theory emphasizes that teachers should encourage students to carry out measurable acts to meet the required skills and competencies.

The Functionalist Theory of Attitudes by Katz adopted from Liska; Handbook of Social Psychology points out that attitudes are determined by the function they serve for people. He takes the view that one is more likely to change his attitude if doing so, allow him to fulfill his goals. Hence, teachers' favorable attitude towards OBE is deemed essential to meet the desired goal of successfully implementing this new paradigm shift in the educational system.

The Commission on Higher Education (CHED) pursues to strengthen the quality assurance system in Philippine higher education. It is mandatory to upgrade and improve higher education curricular offerings to meet global competitions. (Pring-Valdez, 2012). It pushed the Memorandum Order No. 46, series of 2012. Article 3 Section 13, states CHED's commitment to the OBE implementation approach to Quality Assurance (QA) monitoring and evaluation.

OBE is an approach to education, as well as a type of learning wherein decisions about the curriculum, are driven by the exit learning outcomes that the students should display at the end of the course (Borsoto, Santorce, and Lescano, 2014). Spady (1994) stated that OBE is designed so that all students are equipped with knowledge, skills, and qualities needed to be successful after they exit the educational system. Furthermore, Spady (1998) stressed out that what has been lacking is a clear and thoughtful interpretation of what OBE is, why it is needed, and how it operates. The beginning of the process of curriculum change existed in the manifestation of concerns, needs, and dissatisfaction with the curriculum practices of the time, creating a need for variation.

There are different definitions of OBE. CHED defines OBE as an approach that focuses and organizes the educational system around 
which is essential for all learners to know, value and be able to do to achieve the desired level of competence and skills (CHED Handbook on Typology, OBE and ISA 2014).

Another most widely used are the four principles suggested by Spady (1994). The first is clarity of focus. This concept suggests that teachers must focus on what they want students to know, understand, and be able to do. Next is designing down, which means that the curriculum design must start with a clear definition of the intended outcomes that students are to achieve by the end of the program. Another is high expectations, which means that teachers should establish high, challenging standards of performance to encourage students to engage deeply in what they are learning. Lastly, are expanded opportunities. Educators must develop a curriculum that gives scope to every learner to learn in his/her own pace.

OBE is also an approach to education in which decisions about the curriculum are driven by the learning outcomes that students should display at the end of the course. These decisions include curriculum content, educational strategies, student selection, and Assessment (Mohamed Nadzri Mohd Yusoff, 2007). An OBE curriculum means starting with a clear picture of what is essential for students to be able to do, then organizing the curriculum, instruction, and assessment to make sure this learning ultimately happens (Spady, 1994). Learning outcomes are statements of what students can do as a result of learning experiences. Spady (1994) emphasized that outcomes are not merely the things students believe, feel, remember, know, and understand. Instead, outcomes are what students actually can do with what they know and understand.

The Revised Blooms> Taxonomy identified appropriate action verbs in formulating the intended learning outcomes (ILO). These suggested action verbs are integrated into the specified six levels of cognitive learning, which includes remembering, understanding, applying, analyzing, evaluating, and creating (Krathwohl, 2002). Biggs and Tang, (2011) suggested that in formulating the ILOs, it is vital to put them aligned with the universityss, department ss or program >s ILOs. It might not be possible for the course to link with all ILOs of the program or department, but it has to be linked or related to at least one.

Teaching-Learning Process (TLP). Teaching-learning process aimed at activating the action verbs in Intended Learning Outcomes (ILOs). Biggs and Tang (2011) suggested that in planning teaching strategies, 
teachers need to consider the importance of connecting new learnings with previous knowledge where students create conceptual structures integrating their new and old learnings. Whereas, assessment provides the evidence needed to document and validate that meaningful learning has occurred in the classroom (Wiggins and McTighe, 2005).

A study conducted by De Guzman et al. (2017) on Understanding the Essence of the Outcomes-Based Education (OBE) and Knowledge of its Implementation in a Technological University in the Philippines, revealed that the faculty members manifest a great extent of understanding of OBE primarily the active participation of students in the learning activities. Furthermore, the faculty members reported a great extent of knowledge of the OBE, mainly in the use of different techniques to assess student learning.

The findings of Ortega and Ortega-de la Cruz (2016) on Educators> Attitude towards OBE Approach in English Second Language Learning showed that the respondents have a positive attitude towards OBE, in terms of their knowledge, belief, feelings, acceptance level and readiness in handling and facilitating an English Second Language class. Most respondents believed that OBE would allow them to be more flexible in employing a variety of teaching methods in an ESL class.

The findings in the study of Hood (1999) on Teachers> Attitudes towards the Implementation of OBE in South Africa concluded that the attitudes, perceptions, and feelings of competence of teachers will either aid or hinder a successful implementation of OBE. The results might indicate that unless significant changes in teacher attitudes towards OBE are developed through appropriate interventions, its implementation could encounter serious problems.

In the study conducted by Laguador and Dotong (2014) on Knowledge versus Practice on the OBE Implementation revealed that there is a great extent in terms of knowledge and practice on OBE implementation among the faculty members, however there is a moderate extent on the level of understanding of faculty members on the appropriate assessment method utilized. The study also found out that faculty members with a high level of knowledge and understanding of the implementation of OBE also have higher possibility to contribute to the realization of the objectives of OBE through practice.

Borsoto, et al (2014) in their study on the Status of Implementation and Usefulness of Outcomes-Based Education in the Engineering department 
of an Asian university proposed that practice, seminars, the intensive orientation of syllabus and assessment procedure and conducting field trip and training enhance and improve the knowledge and skills of the students.

On the other hand, a study conducted by Akhmadeeva, Hindy and Sparrey (2013) on Overcoming Obstacles to Implementing an OBE Education Model: Traditional versus Transformational OBE, class size, expectations of learner characteristics and reality, teaching practice and evaluation, and student motivation were the most commonly discussed and reported challenges of the teachers in the OBE implementation.

A study of Rajaee (2013) concluded that the implementation of OBE should be a cyclic continuously improving process. The assessment of the outcomes is not the end, but just the means to achieve the desired outcomes.

If educators are to meet the public demands, industry needs, quality education, and for more suitable curriculum outcomes, they need to learn and be aware of the different factors that enhance the implementation of innovation. One essential step in this direction is really to evaluate current $\mathrm{OBE}$ practices and identify those who have been doing well in its implementation. The results can then be applied to guide higher educational institutions who make an effort to implement OBE and maybe perhaps even those who would like to attempt to employ any innovation or change in the education system.

This study aimed to determine the attitude of the teachers towards Outcomes-Based Education (OBE) and assessed the level of its implementation in the University of Bohol in the Second Semester of the School Year 2018-2019.

Specifically, it sought to answer the following questions:

1. What is the demographic profile of the teachers in terms of the following:

1.1. age;

1.2. length of teaching experience; and

13. highest educational attainment?

2. What is the teachers' attitude towards OBE implementation? 
3. What is the teachers' assessment on the implementation of OBE in terms of the following:

3.1. formulation and alignment of learning outcomes;

3.2. curriculum content and structure;

3.3. teaching learning process; and

3.4. outcomes- Based assessments?

4. There is no significant relationship between the teachers' demographic profile and:

4.1. attitude towards $\mathrm{OBE}$; and

4.2. level of implementation?

5. There is no significant correlation between teachers' attitude and teachers' level of OBE implementation?

\section{METHODOLOGY}

A descriptive method was formulated to determine the attitude of the 64 full-time college teachers of the University of Bohol towards OBE and the level of its implementation. The teachers' demographic profiles were also identified to assess its overall significance. The respondents of the study belong to different departments and are handling subjects in line in their field of specialization.

The quantitative data of the study were gathered using a survey questionnaire patterned from the work of Ortega and Ortega De La Cruz (2016) of UP Los Baños for Section II Teachers' attitude towards OBE implementation. Section III of the questionnaire on teachers' level of OBE implementation was also patterned from the study of Evardo (2016).

The researcher assured the respondents of the confidentiality of the information they gave and complete anonymity of the sources of information. The study underwent the rigorous scrutiny of the Research Ethics Committee of the University of Bohol

\section{RESULTS AND DISCUSSIONS}

Table 1 shows that majority of the respondents were in the age ranged of 40 years old and above. This implies that the respondents enjoyed their teaching job in the university and will continue teaching until the retirement age. In addition, positive institutional culture and strong community feelings 
also strengthen the ties of loyalty which in turns preserves teachers' commitment to their teaching profession.

Table 1. Respondents' Profile

$(\mathrm{N}-64)$

\begin{tabular}{|c|c|c|c|}
\hline \multicolumn{2}{|c|}{ Demographic Profiles } & \multirow{2}{*}{$\begin{array}{l}\text { Frequency } \\
15\end{array}$} & \multirow{2}{*}{$\begin{array}{l}\text { Percentage } \\
23.44\end{array}$} \\
\hline Age & 20-29 years old & & \\
\hline & $30-39$ years old & 10 & 15.63 \\
\hline & 40 years old and above & 39 & 60.93 \\
\hline \multirow{3}{*}{$\begin{array}{l}\text { Length of } \\
\text { Teaching } \\
\text { Experience }\end{array}$} & Below 15 years & 30 & 46.87 \\
\hline & $15-29$ years & 30 & 46.87 \\
\hline & 30 years $\&$ above & 4 & 6.26 \\
\hline \multirow{3}{*}{$\begin{array}{l}\text { Highest } \\
\text { Educational } \\
\text { Attainment }\end{array}$} & $\begin{array}{l}\text { Bachelor's Degree Holder } \\
\text { (Bachelor Degree and with Master's units) }\end{array}$ & 13 & 20.31 \\
\hline & $\begin{array}{l}\text { Master's Degree } \\
\text { (Master's Degree and with PhD units) }\end{array}$ & 37 & 57.81 \\
\hline & $\begin{array}{l}\text { Doctorate Degree } \\
\text { (PhD Holder) }\end{array}$ & 14 & 21.88 \\
\hline Total & & 64 & 100 \\
\hline
\end{tabular}

Table 1 further reveals that the length of service to the university is in two groups. One group is below 15 years and the other group is 15 to 29 years of service. Most of the respondents stayed longer because they find the process of teaching in the university socially meaningful and enjoyable. On the other hand, the university is also hiring new teachers as reflected in one of the highest groups, below 15 years. These teachers may have teaching experience from other schools or fresh graduates from the university with good scholastic records. Majority of the respondents are Master's Degree holder. This entails that the respondents have great desire and enthusiasm for professional growth through continuing education which is deemed essential in attaining excellence in work performance and increasing the quality of teaching. 
Table 2. Teachers' Attitude Towards OBE Implementation

\begin{tabular}{|c|c|c|}
\hline Items As a faculty: & WM & Description \\
\hline $\begin{array}{l}\text { 1. I believe that most OBE approaches prepare the students better for } \\
\text { the workplace }\end{array}$ & 3.69 & HF \\
\hline $\begin{array}{l}\text { 2. I believe that OBE will raise the standards of students' academic } \\
\text { achievements in all subject areas }\end{array}$ & 3.59 & HF \\
\hline $\begin{array}{l}\text { 3. I believe that an OBE approach to learning would require more } \\
\text { liaisons with industry }\end{array}$ & 3.66 & HF \\
\hline $\begin{array}{l}\text { 4. I believe that } \mathrm{OBE} \text { will allow me to be more flexible in employing a } \\
\text { variety of teaching methods in my class }\end{array}$ & 3.73 & HF \\
\hline $\begin{array}{l}\text { 5. I believe that OBE approach will provide all students with equal } \\
\text { educational opportunities }\end{array}$ & 3.50 & HF \\
\hline $\begin{array}{l}\text { 6. I feel that } \mathrm{OBE} \text { approaches require more responsibilities from } \\
\text { academics than content driven approaches }\end{array}$ & 3.53 & HF \\
\hline 7. I feel that an OBE approach would not be a waste of time & 3.50 & $\mathrm{HF}$ \\
\hline $\begin{array}{l}\text { 8. I feel that traditional pen and paper tests to assess student } \\
\text { competencies do not always benefit the students. }\end{array}$ & 3.19 & $\mathrm{~F}$ \\
\hline 9. I feel that OBE approach is the best learning approach & 3.33 & HF \\
\hline $\begin{array}{l}\text { 10. I feel that OBE will provide me with an opportunity to ensure that all } \\
\text { learners achieve success }\end{array}$ & 3.38 & HF \\
\hline $\begin{array}{l}\text { 11. I am willing to organize my daily schedule to have adequate } \\
\text { preparation time for OBE approaches }\end{array}$ & 3.50 & HF \\
\hline $\begin{array}{l}\text { 12. I am willing to use any available resources to present my lesson } \\
\text { using OBE approaches }\end{array}$ & 3.61 & HF \\
\hline $\begin{array}{l}\text { 13. I believe that my experience in teaching will help me adapt to an } \\
\text { OBE approaches of learning }\end{array}$ & 3.53 & HF \\
\hline $\begin{array}{l}\text { 14. I am willing to do a lot of subject- related readings in order to improve } \\
\text { my knowledge and understanding of OBE approaches }\end{array}$ & 3.63 & HF \\
\hline $\begin{array}{l}\text { 15. I am willing to attend seminars and trainings relevant to the } \\
\text { preparation and implementation of OBE }\end{array}$ & 3.70 & HF \\
\hline $\begin{array}{l}\text { 16. I am willing to formulate the course and program outcomes aligned } \\
\text { to the institutional outcomes }\end{array}$ & 3.61 & HF \\
\hline $\begin{array}{l}\text { 17. I am willing to deliver the written curriculum that has been designed } \\
\text { in the course syllabi }\end{array}$ & 3.53 & HF \\
\hline $\begin{array}{l}\text { 18. I am willing to use different assessment tools to evaluate students' } \\
\text { progress }\end{array}$ & 3.66 & HF \\
\hline 19. I am willing to assess students' progress using rubrics & 3.69 & $\mathrm{HF}$ \\
\hline $\begin{array}{l}\text { 20. I am willing to shift from content-based approach to outcomes-based } \\
\text { approach in the teaching learning process }\end{array}$ & 3.66 & HF \\
\hline Overall Mean & 3.56 & HF \\
\hline
\end{tabular}

Legend: Interpretation
3.25 - 4.00 Highly Favorable (HF)
$1.75-2.49$ Unfavorable (U)
$2.50-3.24$ Favorable (F)
1 - 1.74 Highly Unfavorable (HU) 
Table 2 reveals that the respondents have highly favorable attitude towards OBE implementation, with higher emphasis on believing that OBE will allow them to be more flexible in employing variety of teaching methods in the class and are likewise willing to attend seminars and trainings relevant to the preparation and implementation of OBE. The results coincide with the study of Ortega and Ortega-dela Cruz (2016) whose findings revealed that the respondents of the study believed that OBE will allow them to be flexible in employing variety of teaching methods in the ESL class.

Table 3.1 OBE Implementation in the Area of Formulation and Alignment of Learning Outcomes

\begin{tabular}{|c|c|c|}
\hline A. Formulation Learning Outcomes & WM & Description \\
\hline 1. I formulate the intended learning outcomes of the institution & 3.27 & $\mathrm{MH}$ \\
\hline 2. I formulate the program learning outcomes & 3.23 & $\mathrm{MH}$ \\
\hline 3. I formulate the course learning outcomes & 3.3 & $\mathrm{EH}$ \\
\hline 4. I formulate the students' learning outcomes as instructional target & 3.38 & $\mathrm{EH}$ \\
\hline 5. I develop the learning outcomes for cognitive level & 3.33 & $\mathrm{EH}$ \\
\hline 6. I develop the learning outcomes for psychomotor level & 3.34 & $\mathrm{EH}$ \\
\hline 7. I develop the learning outcomes in the effective level domain & 3.34 & $\mathrm{EH}$ \\
\hline $\begin{array}{l}\text { 8. I construct the graduate outcomes primarily based on vision, mission } \\
\text { statement of the school }\end{array}$ & 3.41 & $\mathrm{EH}$ \\
\hline \multicolumn{3}{|l|}{ B. Alignment of Learning Outcomes } \\
\hline 9. I align the program outcomes for the institutional outcomes & 3.56 & $\mathrm{EH}$ \\
\hline 10. I align the course learning outcomes to the program outcomes & 3.61 & $\mathrm{EH}$ \\
\hline $\begin{array}{l}\text { 11. I align the instructional learning outcomes to the course learning } \\
\text { outcomes }\end{array}$ & 3.64 & $\mathrm{EH}$ \\
\hline $\begin{array}{l}\text { 12. I transform the course outcomes to long-term outcomes that are } \\
\text { related to students' future life roles. }\end{array}$ & 3.55 & $\mathrm{EH}$ \\
\hline Composite Mean & 3.41 & $\mathrm{EH}$ \\
\hline
\end{tabular}

Legend: Interpretation
$3.25-4.00$
Extremely High (EH)
$2.50-3.24$
Moderately High (MH)
$1.75-2.49$
$1-1.74$
Low (L)
Very Low (VL)

Table 3.1 shows that majority of the respondents answered extremely high in the areas of formulation and alignment of learning outcomes, with higher emphasis on the alignment of the instructional learning outcomes to the course learning outcomes. On the other hand, the formulation of 
the intended learning outcomes of the institution earned the least WM. This means that the respondents were moderately involved in the crafting of the institutional learning outcomes. Since OBE implementation is in its early years, most of the workshops for its planning stage including the formulation of the institutional learning outcomes were mostly participated by the school administrators.

Table 3.2 OBE Implementation in the Area of Curriculum Content and Structure

\begin{tabular}{lcc}
\hline Curriculum Content and Structure & WM & Description \\
\hline $\begin{array}{l}\text { 1. I implement the learning plan as a guide to engage with the } \\
\text { learners in the teaching-learning process }\end{array}$ & 3.48 & EH \\
$\begin{array}{l}\text { 2. I deliver the written curriculum that has been designed in the } \\
\text { course syllabi }\end{array}$ & 3.48 & EH \\
$\begin{array}{l}\text { 3. I enhance the course syllabi that show the relationship of } \\
\text { program outcomes to institutional outcomes and course outcomes } \\
\text { to program outcomes }\end{array}$ & 3.52 & EH \\
$\begin{array}{l}\text { 4. I facilitate the students' learning to enhance knowledge and } \\
\text { skills into high level performance }\end{array}$ & 3.52 & EH \\
$\begin{array}{l}\text { 5. I facilitate the curriculum content to attain the learning outcomes } \\
\text { Composite Mean }\end{array}$ & 3.56 & $\mathrm{EH}$ \\
\hline
\end{tabular}

Legend: Interpretation
$3.25-4.00 \quad$ Extremely High $(\mathrm{EH})$
$1.75-2.49$
Low (L)
$2.50-3.24$ Moderately High $(\mathrm{MH})$
$1-1.74$
Very Low $(\mathrm{VL})$

Table 3.2 indicates that that majority of the respondents answered extremely high in areas of curriculum content and structure with higher emphasis on facilitating the curriculum content to attain the learning outcomes. However, results also reveal more improvement particularly on the implementation of the learning plan in the delivery of the instructions and in carrying out the written curriculum that has been designed in the course syllabi. 
Table 3.3 OBE Implementation in the Area of Teaching-Learning Process

\begin{tabular}{|c|c|c|}
\hline Teaching- Learning Process & WM & Description \\
\hline 1. I deliver instruction through student-centered approach & 3.56 & $\mathrm{EH}$ \\
\hline $\begin{array}{l}\text { 2. I align the teaching-learning activities and the intended learning } \\
\text { outcomes }\end{array}$ & 3.58 & $\mathrm{EH}$ \\
\hline 3. I align the teaching-learning activities and the assessment task & 3.56 & $\mathrm{EH}$ \\
\hline $\begin{array}{l}\text { 4. I align the teaching methods and strategies with the goals } \\
\text { identified in the learning outcomes }\end{array}$ & 3.53 & $\mathrm{EH}$ \\
\hline $\begin{array}{l}5.1 \text { identify the teaching and learning activities that facilitate the } \\
\text { achievement of course learning outcomes }\end{array}$ & 3.53 & $\mathrm{EH}$ \\
\hline $\begin{array}{l}\text { 6. I motivate the students' understanding on the outcomes they are } \\
\text { meant to achieve }\end{array}$ & 3.59 & $\mathrm{EH}$ \\
\hline $\begin{array}{l}\text { 7. I emphasize the knowledge and content (Cognitive domain) in } \\
\text { the teaching and learning activities }\end{array}$ & 3.56 & $\mathrm{EH}$ \\
\hline $\begin{array}{l}\text { 8. I emphasize students' skills and competencies (psychomotor } \\
\text { domain) in the teaching and learning activities }\end{array}$ & 3.53 & $\mathrm{EH}$ \\
\hline $\begin{array}{l}\text { 9. I emphasize the values and attitudes in the teaching learning } \\
\text { activities }\end{array}$ & 3.61 & $\mathrm{EH}$ \\
\hline $\begin{array}{l}\text { 10. I facilitate the learning activities for different types of learners in } \\
\text { the diverse environment }\end{array}$ & 3.53 & $\mathrm{EH}$ \\
\hline Composite Mean & 3.56 & $\mathrm{EH}$ \\
\hline
\end{tabular}

Legend: Interpretation
$3.25-4.00 \quad$ Extremely High $(\mathrm{EH})$
$1.75-2.49$
Low (L)
$2.50-3.24$ Moderately High $(\mathrm{MH})$
$1-1.74$
Very Low (VL)

Table 3.3 shows that majority the respondents answered extremely high in the area of teaching-learning process with higher emphasis on instilling values and attitudes in the teaching learning activities. The result implies that the respondents were not only concerned on the academic performance of the students, but instilling good values and attitudes is also on top priority. 
Table 3.4 OBE Implementation in the Area of Assessment

\begin{tabular}{llc}
\hline Assessment & WM & Description \\
\hline $\begin{array}{l}\text { 1. I use different assessment tools to evaluate students' progress } \\
\text { 2. I assess students' knowledge }\end{array}$ & 3.42 & $\mathrm{EH}$ \\
3. I assess students' skills and competencies & 3.66 & $\mathrm{EH}$ \\
$\begin{array}{l}\text { 4. I assess students' values and attitudes } \\
\text { 5. I align the teaching methods and assessment methods }\end{array}$ & 3.53 & $\mathrm{EH}$ \\
$\begin{array}{l}\text { 6. I align the assessment procedure and tools to the learning } \\
\text { outcomes }\end{array}$ & 3.63 & $\mathrm{EH}$ \\
$\begin{array}{l}\text { 7. I develop rubrics to assess the attainment of the institutional } \\
\text { outcomes }\end{array}$ & 3.5 & $\mathrm{EH}$ \\
$\begin{array}{l}\text { 8. I develop rubrics to assess the attainment of program outcomes } \\
\text { 9. I develop rubrics to assess the attainment of course outcomes } \\
\text { 10. I assess the level of students performance compared with the } \\
\text { intended learning outcomes }\end{array}$ & 3.55 & $\mathrm{EH}$ \\
Composite Mean & EH & EH \\
\hline
\end{tabular}

Legend: Interpretation
$3.25-4.00 \quad$ Extremely High (EH)
$1.75-2.49$
Low (L)
$2.50-3.24$ Moderately High $(\mathrm{MH})$
$1-1.74$
Very Low $(\mathrm{VL})$

Table 3.4 reveals that majority of the respondents answered extremely high in the area of assessment with higher emphasis on assessing students' skills and competencies, while, reported on lower level is in the used of different assessment tool to evaluate students' progress.

\subsection{Relationship between Teachers' Demographic Profile and Attitude towards OBE}

\begin{tabular}{|c|c|c|c|c|c|c|}
\hline Variables & Mean & $\begin{array}{l}\text { Mean } \\
\text { Attitude }\end{array}$ & $\begin{array}{l}\text { Computed } \\
\text { Value }\end{array}$ & $\begin{array}{l}\text { Critical } \\
\text { Value @ } \\
0.05\end{array}$ & p-value & Decision \\
\hline Age & 41.03 & & $r=0.0144$ & 0.2482 & 0.91 & Accept Ho \\
\hline $\begin{array}{l}\text { Length of teaching } \\
\text { experience }\end{array}$ & 14.30 & 3.56 & $r=0.2200$ & 0.2482 & 0.70 & Accept Ho \\
\hline $\begin{array}{l}\text { Highest educational } \\
\text { attainment }\end{array}$ & & & $x^{2}=3.2044$ & 9.49 & 0,96 & Accept Ho \\
\hline
\end{tabular}

Table 4.1 reveals that the computed $r$ value of the teachers' age which is 0.0144 , length of teaching experience 0.2200 , and highest educational 
attainment 3.2044 are lower than their critical values at 0.05 level of significance. The results lead to the acceptance of the null hypothesis. This entails that teachers' demographic profile in terms of age, length of teaching experience and highest educational attainment does not affect their attitudes towards OBE implementation.

The above finding is congruent to the study of Christina Giesel-Hood (1999) who also concluded that there were no significant differences between the attitudes of teachers towards OBE among teachers of different age groups, different years of teaching experience, different amounts of exposure to OBE training, and between teachers working at different types of schools and political orientations.

\subsection{Relationship between Teachers' Demographic Profile and Level of OBE Implementation}

\begin{tabular}{lccllll}
\hline Variables & Mean & $\begin{array}{l}\text { Mean OBE } \\
\text { Implementation }\end{array}$ & $\begin{array}{l}\text { Computed } \\
\text { Value }\end{array}$ & $\begin{array}{l}\text { Critical } \\
\text { Value @ } \\
0.05\end{array}$ & p-value & Decision \\
\hline Age & 41.03 & & $r=0.3120$ & 0.2482 & 0.04 & Reject Ho \\
$\begin{array}{l}\text { Length of } \\
\text { teaching } \\
\text { experience }\end{array}$ & 14.30 & 3.51 & $r=0.2200$ & 0.2482 & 0.08 & Accept Ho \\
$\begin{array}{l}\text { Highest educational } \\
\text { attainment }\end{array}$ & & & & & \\
\hline
\end{tabular}

Table 4.2 reveals that the computed $r$ value of age which is 0.3120 is higher than the critical value of 0.2482 at 0.05 level of significance. The result leads to the rejection of the null hypothesis. The result implies that teachers' age has direct relationship on their willingness to carry out the overall processes of OBE implementation. Since majority of the respondents are in the age ranged of 40 years old and above, hence, considered experienced teachers. Through experience, teachers would be able to weigh and assess their strengths and weaknesses, hence it will lead for further improvement of their skills and potential in carrying out the tasks entrusted to them.

On the other hand, the computed r-value for length of teaching experience which is 0.2200 is lower than the critical value of 0.2482 at 0.05 level of significance; meanwhile, the computed r-value of highest educational attainment which is 6.2363 is lower than the critical value of 9.49 at 0.05 level of significance. The results lead to the acceptance 
of the null hypothesis. These imply that teachers' years of service in the university is not a factor in the implementation of OBE, same as teachers' educational qualifications. This is simply because OBE is an institutional endeavor; hence, it is a requirement to all teachers, so it must be followed.

Table 5. Significant correlation between Teachers' Attitude towards OBE and its Level of Implementation

\begin{tabular}{lccccc}
\hline Variables & Mean & r-value & $\begin{array}{l}\text { r-criticalvalue } \\
@ 0.05\end{array}$ & p-value & Decision \\
\hline $\begin{array}{l}\text { Teachers' Attitude } \\
\text { towards OBE }\end{array}$ & 3.56 & & 0.2482 & 0.000001 & Reject Ho \\
$\begin{array}{l}\text { Teachers' Level of OBE } \\
\text { Implementation }\end{array}$ & 3.51 & 0.5618 & & & \\
\hline
\end{tabular}

Table 5 shows that the computed r-value of 0.5618 is greater than the critical value of 0.2482 at $62 \mathrm{df}, 0.05$ level of significance. On the other hand, the $P$ value of 0.000001 is less than 0.05 . The results lead to the rejection of the null hypothesis. These findings indicate that there is a direct relationship between teachers' attitude towards OBE and its level of implementation. It suggests that teachers who have favorable attitude towards OBE are at the same time willing to execute and carry out the overall processes of OBE implementation. The result matched with the study of of Laguador and Dotong (2014) that faculty members with high level of knowledge, understanding and attitude on the implementation of OBE have also higher possibility to contribute in the realization of the objectives of OBE through practice. The said finding is also anchored on Katz's Functionalist theory of attitude. According to Katz (1960), attitudes are determined by the function they serve for people. He takes the view that people hold given attitude because these attitudes help them achieve their basic goals. One's attitude towards something greatly affects the amount of effort he is willing to spare to attain it.

\section{CONCLUSION}

Based on the findings revealed in this study, it is hereby concluded that the attitudes fostered by the teachers will either help or hamper the successful implementation of OBE. Teachers who posses favorable attitude towards OBE are those teachers who are willing to execute and carry 
out the overall processes of OBE implementation. Intensive OBE training programs hosted by skilled trainers need to be implemented to enhance teachers' attitudes and feelings of competence in carrying out the tasks necessitate the overall OBE implementation. With a strong determination combine with effective collaboration between school administrators and teachers, indeed successful implementation of this new paradigm shift in the educational system will reach far beyond one could imagine.

\section{REFERENCES CITED}

Akhmadeeva, L., Hindy, M., \& Sparrey, C. J. (2013). Overcoming obstacles to implementing an outcome- based education model: Traditional versus transformational OBE. Proceedings of the Canadian

Engineering Education Association (CEEA). Retrieved from https://bit. ly/2YIUby3 (accessed last January 5, 2019)

Biggs, John, Tang Catherine (2011). Teaching for Quality Learning at University. $4^{\text {th }}$ Ed. Berkshire, England. Retrieved from https://bit. ly/2TvQtCm (accessed last December 16, 2018)

Bloom, B. S. (1968). Learning for Mastery. Instruction and Curriculum. Regional Education Laboratory for the Carolinas and Virginia, Topical Papers and Reprints, Number 1. Evaluation comment, 1(2), n 2 . Retrieved from https://bit.ly/2KFcElm (accessed last November 5, 2018)

Borsoto, L. D., Lescano, J. D., Maquimot, N. I., Santorce, M. J. N., Simbulan, A. F., \& Pagcaliwagan, A. M. (2014). Status of implementation and usefulness of outcomes-based education in the engineering department of an Asian university. International Journal of Multidisciplinary Academic Research, 2(4), 14-25. Retrieved from https://bit.ly/2TkdRSz ( accessed last November 6, 2018)

CHED Handbook on Typology, Outcomes-Based Education and Institutional Sustainability Assessment 2014. Retrieved from https:// bit.ly/306xQYd (accessed last November 5, 2018) 
CHED Memorandum Order (CMO) 46, series 2012. Retrieved from https:// bit.ly/2ORERul (accessed last November 5, 2018)

Dalto, Jeffrey (2014). Robert Mager's Performance-Based Learning Objectives. Convergence Training. Retrieved from https://bit. ly/2zMDvpJ (accessed last December 4, 2018)

De Guzman, M. F. D., Edaño, D. C., \& Umayan, Z. D. (2017). Understanding the Essence of the Outcomes-Based Education (OBE) and Knowledge of its Implementation in a Technological University in the Philippines. Asia Pacific Journal of Multidisciplinary Research, 5(4). Retrieved from https://bit.ly/2H3cRxG (accessed last January 4, 2019)

Evardo, Mae (2016). Outcomes-Based Education; Perspective and Preparedness. Holy Name University. Tagbilaran City. (unpublished dissertation).

Giessen-Hood, C. (1999). Teacher's attitudes towards the implementation of outcomes based education (OBE) in South Africa (Doctoral dissertation). Retrieved from https://bit.ly/2OQlimo (accessed last January 4, 2019)

Keating, S. B. (Ed.). (2014). Curriculum development and evaluation in nursing. Springer Publishing Company. Retrieved from https://bit. ly/2MWcc56 (accessed last November 5, 2018).

Krathwohl, D. R. (2002). A revision of Bloom's taxonomy: An overview. Theory into practice, 41(4), 212-218. Retrieved from https://bit. ly/2TqPWBI (accessed last February 4, 2019).

Liska; Handbook of Social Psychology [The cognitive perspective]; Michener et al; Myers; Social Psychology, edited by Arnold Kahn; Retrieved from https://bit.ly/33uYKuE (accessed last November 6, 2018).

Laguador, J. M., \& Dotong, C. I. (2014). Knowledge versus practice on the outcomes-based education implementation of the engineering faculty 
members in LPU. International Journal of Academic Research

Progressive Education and Development, 3(1), 63-74. Retrieved from https://bit.ly/29lHmk4 (accessed last February 6, 2019).

Mohamed Nadzri Mohd Yusoff. (2007). Outcome-Based Education (OBE) Module: Introduction to Learning Outcome. Retrieved from https://bit. ly/2Z43Drr (accessed last November 5, 2018).

Pring-Valdez, A. (2012). Curriculum Model for Medical Technology: Lessons from International Benchmarking. Online Submission, 3, 292-301. Retrieved from https://bit.ly/33mAHOW (accessed last February 3, 2019).

Rajaee, N., Junaidi, E., Taib, S. N. L., Salleh, S. F., \& Munot, M. A. (2013). Issues and challenges in implementing outcome based education in engineering education. International Journal of I n n o v a t i o n Education and Research, 1(4), 1-9. Retrieved from 2yWGEUg (accessed last February 7, 2019).

Rose, A. A., Ortega, R. A., \& Ortega-Dela, C. (2016). Educators' Attitude towards Outcomes-Based Educational Approach in English Second Language Learning. American Journal of Educational Research, 4(8), 597-601. Retrieved from https:// bit.ly/2WCQbtY (accessed last August 4, 2018).

Spady, W. G. (1998). Paradigm Lost: Reclaiming America's Educational Future. AASA Distribution Center, 1801 N. Moore St., Arlington, VA 22209. Retrieved from https://bit.ly/2Tq29X4 (accessed last November $5,2018)$.

Spady, W. G. (1994). Outcome-Based Education: Critical Issues and Answers. American Association of School Administrators, 1801 North Moore Street, Arlington, VA 22209. Retrieved from https://bit. Iy/2AK3la2 (accessed last September 4, 2018).

Wiggins, G., \& McTighe, J. (2005) Understanding by design (2nd ed.). Alexandria, VA: Association for Supervision and Curriculum Development ASCD. Retrieved from https://bit.ly/2HgM3KL (accessed last January 6, 2019). 